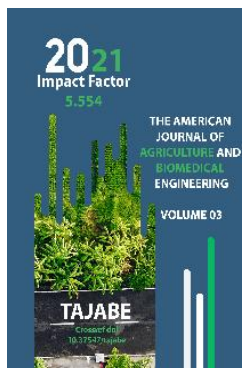

\section{The Effect Of Gypsum Content And Seasonal Variations On The Enzyme Activity And Respiration Properties Of Heavy Soils In Reclamation Status}

Makhkamova D.Yu.

Doctor Of Biological Sciences (Phd), National University Of Uzbekistan Named After Mirzo Ulugbek, Uzbekistan
Journal Website: http://theamericanjour nals.com/index.php/taj abe

Copyright: Original content from this work may be used under the terms of the creative commons attributes 4.0 licence.

\title{
ABSTRACT
}

This article discusses the effect of gypsum content and seasonal variations on the enzyme activity and respiration properties of bad melioration content of soil in Uzbekistan. Furthermore, this paper provides some datas about their origins and how to eliminate it.

\section{KEYWORDS}

Peroxidase, enzyme, water-resistant, desert soil, sierozem, humus horizon, lowest fementative activity, respiration, gypsum-abundant, abundant soils, irrigated swampy-meadow soil.

\section{INTRODUCTION}

Soil is a structural product with a complex characterization, which in turn is noted to have a relatively stable level of enzyme activity, specific to certain types of specific soil formation. The formation of the enzyme potential of the soil is a complex process, such as the formation of the soil itself, which is the product of the interaction of environmental factors in the formation of the soil. In the processes of decomposition and synthesis of organic matter in the soil cover, the exchange of matter and energy takes place in the presence of enzymes. Enzyme activity is also high in water-resistant aggregates in the soil [4, pp. 398-407; 5, p. 174]. As a result of enzymatic processes, difficult-to-assimilate substances in the soil layer are converted into easily assimilated forms by plants and microorganisms. In turn, the fertility of the soil is also directly related to the enzymatic processes that take place in the soil. In desert soils, the redox process is active, and in humid 
conditions, the activity of hydrolytic enzymes is observed [3, pp. 12-16; 5, p. 174].

\section{THE MAIN FINDINGS AND RESULTS}

The use of ecological principles of a systemic nature in clarifying the causal relationship of enzyme activity of soils with environmental indicators in the context of the influence of various regulatory factors of the external environment forms the theoretical basis for modeling changes in this situation. The development of models of this type is important for the purpose of managing soil fertility, for predicting changes in enzyme activity and control factors [5, p. 174; 7, p. 96].

Many researchers directly link the activity of enzymes, including catalase, to the amount of humus in the soil. In most cases, catalase activity is recorded in the upper horizons of the soil, as it descends into the deeper layers along the soil section, its activity level decreases. Under optimal conditions of heat and humidity, the activity of biological processes in the soil layer does not decrease almost all year round [1; 2, pp. 88-99; 6, pp. 1481-1486; 8, p. 314]. Peroxidase in soil is involved in important processes such as soil fertility, synthesis and decomposition of humus substances, decomposition of phenolic compounds in plant residues and transformation of hydrolysis products of herbicides [3, pp. 12-16; 5, p. 174; 7, p. 96].

The results of the study showed that the amount of catalase activity was relatively active in the average amount of gypsum in the reserve sierozem-meadow gypsum and meadow-saline gypsum, the amount of oxygen released in the soil layer for 5 minutes, respectively, per 1 gram of soil $\mathrm{O}_{2}$ - in the spring - 13, 8-11.0 ml, in summer - 11.0-9.2 ml and in autumn - 12.1-9.3 ml. Also, the next place in terms of the value of this indicator is occupied by a layer of typical sierozem-soils, in which $\mathrm{O}_{2}$ released in 5 minutes per 1 gram of soil - $7.8 \mathrm{ml}$ in spring, $6.6 \mathrm{ml}$ in summer and 6.9 $\mathrm{ml}$ in autumn. In terms of the value of this catalase activity, the next place is occupied by sierozem-meadow soils (respectively, 4.1-2.6$3.5 \mathrm{ml}$ ). In the case of low humus content in irrigated soils, the value of catalase activity is considered to be low compared to protected soils. The dynamics of catalase activity during the year is explained by the fact that the temperature conditions do not have the same description, the amount of moisture in the soil and the degree of aeration vary, the condition of the vegetation cover and other factors.

According to the results of studies on the activity of peroxidase and polyphenol oxidase in soils, the activity of enzymes in protected soils was considered relatively high. The value of the activity of these enzymes in this layer of soil for 24 hours per 100 grams of soil in the spring - 7.6-8.9, in the summer - 5.6-6.8 and in the fall - $6.9-8.0 \mathrm{mg}$ of purpurgallin, as well as Irrigated wetland-meadow soils have a low value (1.42-1.0-1.2 and 2.0-1.6-1.8 mg, respectively). In general, the results obtained indicate that the activity of phenoloxidase enzymes in the composition of protected soils is high, while in irrigated soils it is low.

The activity of the studied enzymes was found to be relatively high in the surface layers of the soil, decreasing downwards. In the studied soils, the value of relative enzymatic activity was mainly recorded in the upper horizons of the soils. Enzyme activity is almost not recorded in relatively deep horizons. In the soil section, enzymatic activity was found to be relatively high on the humus horizon, and with the transition to the next horizon, a sharp decrease in enzymatic activity was observed. The distribution of enzymatic 
activity across the soil section depends on the genetic characteristics of the soil and the characteristics of the soil formation processes that take place in the soil.

If soil microorganisms play an important role in respiration, then climatic factors also affect the process of respiration and soil microorganisms. The results of the study showed that high levels of soil respiration were detected in the protected sierozemmeadow soils, and this value was $12.6 \mathrm{mg} \mathrm{SO} 2$ / $100 \mathrm{~g}$ in spring - 9.6, summer - 9.7 and autumn. The second place in terms of carbon dioxide emissions is occupied by meadowsaline soils, the amount of $\mathrm{SO} 2$ released from these soils is $9.2-7.3-8.1 \mathrm{mg}$, respectively. Soil salinity has been found to have a negative effect on the amount of $\mathrm{SO}_{2}$ released from the soil surface.
In particular, it was noted that with increasing gypsum content in soils, the level of biological activity decreases and the respiration rate is very low. At the same time, in gypsum-rich soils almost two-fold decrease in respiration was found - that is, respectively - 6.3-4.0-5.1 $\mathrm{mg}$, and in sierozem soils - this value was 7.36.4-7.1 mg. formed.

In the layer of irrigated meadow-sierozem soils, the value of this indicator is 7.4-6.3-6.8 mg. In irrigated meadow soils - 5.5-4.2-4.5 mg / $100 \mathrm{~g}$, and in irrigated swampy-meadow soils - 4.4-3.8-4.0 mg / 100 g. It should be noted that in almost all studied soil layers, a decrease in the value of respiration intensity in the direction towards the deeper layers of the soil was observed in Diagram-1.

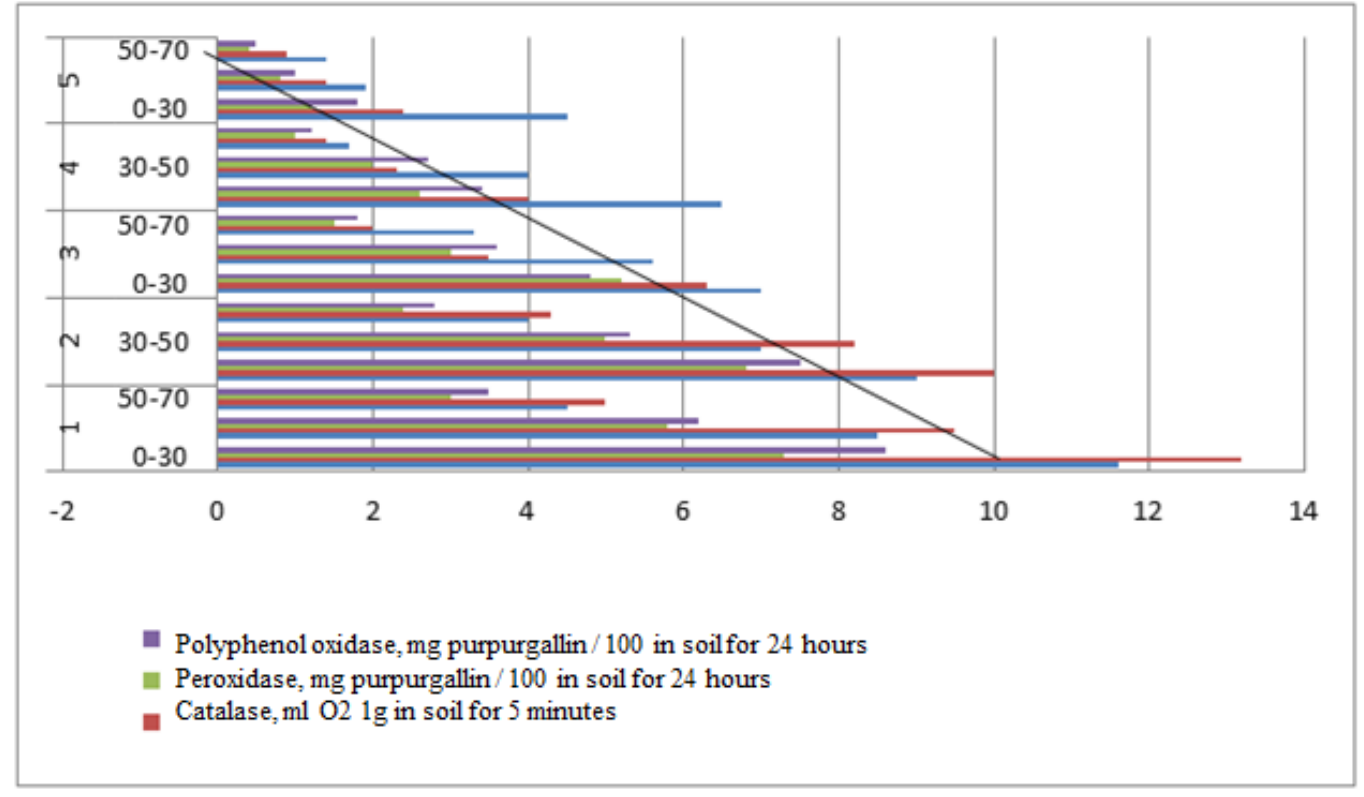

Diagram-1. Respiration and enzymatic activity of gypsum soils 
According to the results obtained, the rate of respiration in soils depends on the processes of soil formation and the properties of the soil.

The fermentative activity of the studied soils decreased in terms of gypsum content, the highest rate was observed in soils with gypsum content below $2 \%$, the lowest fementative activity, respiration rate was observed in gypsum-abundant and very abundant soils. It was found that the reason for this is the increase in the amount of gypsum associated with the physical, chemical, microbiological activity of soils.

\section{CONCLUSION}

The study found that in the spring, when the soil contains incompletely decomposed plant remains, active release of $\mathrm{SO}_{2}$ from the soil is observed under conditions of sufficient humidity and optimal temperature, a significant decrease during the summer and a certain increase in the fall. Also, a relatively large release of $\mathrm{SO}_{2}$ in the studied soils is observed in the upper horizons of the soil, which is characterized by a high content of organic matter in the upper layers of the soil, sufficient nutrients and various substances released by plant roots, optimal aeration in the soil. , the value of respiration rates decreases in the direction towards the deeper layers of the soil, so that the respiration rate of the soil depends on the amount of humus in the soil and the amount of microorganisms.

\section{REFERENCES}

1. Atoev B., Kaypnazorov J., Egamberdieva M., Makhammadiev S., Karimov M., Makhkamova D. Technology of nutriating winter wheat varieties in variety-soil- fertilizer system. E3S Web of Conferences 244, 02040 (2021).

2. Gafurova L.A.,Madrimov R.M., Razakov A.M., Nabiyeva G.M., Matkarimov T. R. Evolution, transformation and biological activity of degraded soils. International Journal of Advanced Science and Technology. Vol. 28, No. 14, (2019), pp. 8899.

3. Makhkamova D. Mechanical composition of gypsum virgin land and irrigated soils zarbdar district of Jizzakh region. The American Journal of Agriculture and Biomedical Engineering, Volume 2 Issue 10, 2020 -P. 12-16.

4. Garbuz S.A., Yaroslavtseva N.V., Kholodov V.A. (2016) Enzymatic activity inside and outside water-resistant aggregates in soils of different types. Journal: Soil Science No. 3. - pp. 398-407. (Garbuz S.A., Yaroslavtseva N.V., Xolodov V.A. Fermentativnaya aktivnost vnutri i snaruji vodo ustoychivix agregatov $\mathrm{v}$ pochvax razno govidaispol'zovaniya. J: Pochvovedeniya № 3. 2016. S. 398-407.)

5. Gafurova L., Makhkamova D. (2020) Gypsum soils of Jizzakh desert and their biological activity. ISBN 978-9943-6469-2-0 MONOGRAPHY. "Innovative Development Publishing House”. - p. 174. (Gafurova L., Maxkamova D. Jizzax cho'li gipsli tuproqlari va ularning biologic faolligi. ISBN 978-9943-6469-2-0 MoNOGRAFIYA. «Innovatsion rivojlanish nashriyot-matbaa uyi» 2020. -174 b.)

6. Dadenko E.V. et al. (2009) Changes in enzymatic activity during storage of soil samples / Soil Science. No. 12. - pp. 14811486. (Dadenko YE.V. i dr. // Izmenenie fermentativnoy aktivnosti prixraneniipochvennix obraztsov / Pochvovedenie. 2009. - № 12. S. 1481 1486.) 
The American Journal of Agriculture and Boimedical Engineering

IMPACT FACTOR (ISSN - 2689-1018)

Published: June 30, 2021| Pages: 61-65

Doi: https://doi.org/10.37547/tajabe/Volume03Issue06-09

OCLC - 1121105746

7. Kozlov K.A. (1964) Enzymatic activity of soils as an indicator of biological activity. Novosibirsk: - p. 96. (Kozlov K.A. Fermentativnaya aktivnost pochv kak pokazatel biologicheskoy aktivnosti. Novosibirsk, 1964. 96 s.)

8. Neklyudov A.D. (2007) The state of the soil and its enzymatic activity // Ecological systems and instruments. No. 3. - p. 314. (Neklyudov A.D. Sostoyanie pochvi i yee fermentativnaya aktivnost I/ Ekologicheskie sistemi i pribori. 2007. - № 3. 314 s.) 